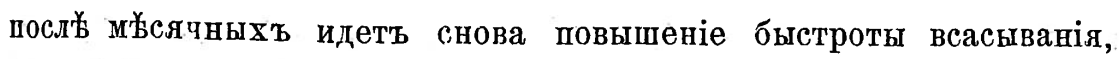
которая, достигнувъ извъстнаго шрельља, держится ва немъ, давая незначительныя колебанія. Къ наступленію м'ьсяqныхъ быстрота снова повышается и т. д. Такихъ ежем'九сячныхъ колебаній въ быстроть всасыванія не наблюдается у дътей и старухъ. У беременныхъ лькарственныя вещества всасываются изъ желудка быстрђе, нежели у небеременныхъ. Возрастъ беременныхъ и скорость всасыванія обратно-пропордіональны другъ другу. По м'ърж⿱宀⿻三丨 приближенія къ концу беременности всасываніе ускиляется. У повторнобеременвыхъ всасываніе идеть скоръе, чъмъ у первобеременныхъ.

H. Какушкинг.

74. М. М. Мироновъ.-Текущіө вопросы по акушерству и гинекологіи въ 1893 г. (Журн. Медицины и Гигіены, 1894 г., № 2).

Авторь сообщаеть почерпнутыя имъ изъ литературы новъйшія данныя по вопросу о воспалительных'ь забольваніяхъ придатковъ матки и об́ ихт л'вченіи (Schauta, Terria, Hartmann, Martin, Gonlliond, Doyen) и объ оперативномъ льчченіи міомь матки (Gottschalk, Küstner, Chrobak, Lennauder, Zweifel, Ommъ).

H. Какушкинг.

75. ऊенщ.-врачь Т. М. Красина.-Случай родовъ четверней. (Акушерка, 1895 г., № 6).

Женщина 35 льътъ, беременна въ 9-й разъ. Седьмые и восьмые роды были двойнями. Настоящая беременность окончилась преждевременно, на 8 м'ъсяцб. Первый и четвертый плоды, женскаго пола, родились произвольно; второй и третій, мужскаго пола, извлечены за ножку. Плоды приблизительно семимвсячнаго возраста. Трое жили по 18 часовъ, одинъ 25 часовъ. „Посль'ъ им'љљ общую ворсистую оболочку, на которой по шериферіи въ четырехъ мъстахъ располагались отды̆льные, небольшіе посльды, а пентр' ворсистой оболочки остался свободнымъ, не занятымъ посльдами". Посльродовой леріодъ протекаль безъ осложненій.

\title{
Н. Какуикинг.
}

76. И. М. Львовъ.-Пороки сердща и бөременность. (Ежене-

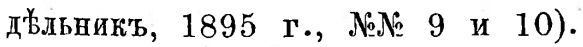

Значеніе пороковъ сердца для беременности оцънивается авторами различно. Одни (Winckel, Fehling) отрицаютъ вліяніе поро ковъ на теченіе беременности, другіе (Spiegelberg, Schröder, Jaзаревичб) придають имъ значеніе, третьи ставять даже пороки сердца противупоказаніемъ для заберемененія. Авторъ, на осно- 